В.С. Отрешко,

кандидат педагогічних наук, дочент НПУ імені М.П.Драгоманова

\title{
ПРІОРИТЕТ ІНТЕЛЕКТУ, СОВІСТІ І КУЛЬТУРИ В СТРУКТУРІ УКРАЇНСЬКОГО ДЕРЖАВОТВОРЕННЯ
}

У сучасному суспільстві базовим процесом життєдіяльності $є$ формування людей 3 належним рівнем знань і системою життєвих цінностей. Це зумовлює зростання вимог до освіти. Її головні завдання - вивчення наукових засад формування інформаційної цивілізації, розвиток у людей практичних навичок використання нових інформаційних і комунікаційних технологій. Ці завдання повинні вирішуватися на засадах дієвого гуманізму, спрямованого на розвиток інтелектуальних здібностей особистості як компетентного фахівця.

Проблемам розвитку інтелектуальної сфери значну увагу в Україні приділяють такі науковці, як: М.Пірко [1], А.Чорний [3], Л.Діденко [5], О.Чопик [8], 3.Самчук [10] та ін. В.Пашков [2], Г.Михайлишин [4, 9], Г.Драйден [6], О.Пунченко [7] досліджували проблеми створення сучасної моделі інноваційної освіти. Ю.Сугробова [18] аналізувала негативні наслідки передачі культурно-просвітницьких функцій приватним структурам. Шляхи розвитку політичної культури, культурологічної функції інтелекту розглядали С.Давидюк [11], Є.Федорова [13], М.Семенова [15], Н. Авер'янова [16], А.Зуєв [17] та ін. Метою нашої статті є визначення шляхів розвитку інтелектуальної сфери суспільства в контексті використання культурологічної функції інтелекту в державотворчих процесах.

Освіта має надзвичайне значення в інформаційному суспільстві, вдосконалюючи вміння окремих людей нестандартно мислити, їхню здатність до оригінального вирішення проблем тощо. Проблема розвитку інтелектуальної сфери в період інформатизації навчання є однією з глобальних світових проблем. Йдеться про гостру проблему освіти взагалі, а не про локальні вдосконалення окремих освітніх систем. Її ідеали, цілі, зміст, методи, технології наче втрачають усталеність, іноді змінюють полярність. Якщо до епохи інформаційної революції наука була орієнтована на збільшення та накопичення знань, то сьогодні вона значною мірою зосереджується 
на засобах оволодіння накопиченим, водночас визнаючи глобальну роль інформаційних технологій в своєму подальшому розвитку [1].

Базовим процесом життєдіяльності глобального соціуму є формування людей 3 певною системою життєвих цінностей. Повнотою і системністю підготовки людини визначаються доцільність, культуровідповідність іiі діяльності в особистісному, суспільно-політичному й соціально-виробничому просторах - діяльності, яка зміцнює інтереси глобального соціуму. У цих умовах освіта повинна бути комплексною, забезпечуючи людині максимальну свободу при виборі системи цінностей і напрямків діяльності, при визначенні іiі особистісної, громадянської й соціальної позиції $[2,77]$.

Розвиток інформаційного суспільства зумовлює зростання вимог до самої системи освіти. Основне іiі завдання в сучасних умовах - пошук та розвиток потенційних здібностей і талантів, насамперед підростаючого покоління. Високотехнологічною країною може стати тільки така країна, яка створить максимальні можливості для реалізації творчих потенцій людини, зуміє поставити їх на службу суспільству [3, 87].

Одним із актуальних завдань сучасної системи освіти має стати інтелектуалізація іiі змісту, вивчення наукових засад формування інформаційної цивілізації, розвиток у людей практичних навичок використання нових інформаційних і комунікаційних технологій.

Водночас не варто ідеалізувати новітні тенденції розвитку системи освіти лише через їх новизну. Г.Михайлишин застерігає: освітньому простору модерного зразка властиві серйозні кризові явища, які слід враховувати, здійснюючи реформування вітчизняної освітньої системи. До них належать:

- $\quad$ формування стійкої тенденції до широкого впровадження інновацій, не пов'язаних 3 традиціями української педагогіки та культури. Це призводить до того, що шкільна освіта позбавляється своєї національної вкоріненості. Відбувається трансформація соціальних орієнтирів підростаючого покоління (наприклад, ідеал співробітництва та колективізму змінюється насаджуванням культу лідерства й індивідуалізму, що призводить до негативних наслідків у житті суспільства);

- $\quad$ набуття освітою чітко утилітарної спрямованості на шкоду фундаментальності. Через прагматичний підхід до цілей і завдань освітнього процесу скасовується його культурологічна функція; 
- зміна підходу до формування особистості у зв'язку з вимогами ринку. На перший план висуваються такі якості характеру, як підприємливість, уміння адаптуватися до мінливих умов ринку. Постійно робляться спроби адміністративно, через модернізацію освіти впровадити нову систему цінностей, що, на думку ряду фахівців, призводить до підвищення нервово-психічних патологій у суспільстві та соціальної нестабільності $[4,418]$.

Визнаючи об'єктивну необхідність реформування сучасної освіти, водночас необхідно всебічно визначати перспективи і наслідки цього процесу. Зокрема, декларування сутності нової ноосферної цивілізації лише як епохи свободи, яка уможливлює інтелектуально-креативний розвиток людини $[5,44]$, залишає осторонь питання особистісної відповідальності за ті динамічні зміни, що відбуваються в сучасному інформаційному просторі. Свобода дійсно $є$ необхідною умовою інтелектуального поступу людства, однак навряд чи можливо вважати іiі саму по собі єдиною достатньою умовою такого поступу.

Не здається прийнятною в якості перспективи розвитку освітньої системи вітчизняного суспільства жорстка дихотомія, яку пропонують Г.Драйден і Дж.Вос: «...Для тих, хто володіє новими знаннями, - світ можливостей, для решти (в час, коли руйнується стара система і зникають старі місця праці) безробіття, злидні й безвихідь» $[6,35]$. У реальних умовах розвитку сучасного українського суспільства подібне протиставлення лише поглиблюватиме кризові явища в соціумі. Натомість, здійснюючи освітню політику, варто підкреслювати, що нові знання (як відповідні можливості) $\epsilon$ доступними всім громадянам - і доцільно не лише декларувати таке право, а й турбуватися про його забезпечення на загальнодержавному рівні.

У сучасній освіті, як зазначає О.Пунченко, виявляються дві прямо протилежні тенденції: зниження можливостей (матеріального характеру) на здобуття якісної вищої освіти і прагнення до розширення гуманізації соціуму. Зниження можливості здобування якісної освіти, набуття фундаментальних основ знань у ВНЗ - це спонтанно зростаючий процес деінтелектуалізації, декультуризації, десоціалізації, моральної деградації, посилення нігілізму в суспільстві. Проблема в тому, що на початку третього тисячоліття, з його невичерпним потенціалом технічного прогресу, освіта стикається 3 
реальними перспективами свого однобічного розвитку (зокрема, абсолютизацію значення інформаційно-комунікаційних технологій не можна не оцінити як новий варіант технократизму). Духовна синергія в освіті виявляє ії позитивну складову, що дає можливість значною мірою уникнути песимістичних висновків в оцінці загальних перспектив освітнього розвитку. Це - напрям гуманізації освіти і самої людини. Гуманізація стихійно виявлялася в суспільних відносинах, освіті й інтеракціях людей протягом усієї історії, закріплюючись у нормах моралі, права, культури. Становлення ж інформаційної цивілізації потребує формування наукового знання на основі практично дієвого гуманізму [7, 18-19].

Тож не є випадковим те, що у програмі інтелектуалізації суспільства значна роль відводиться освіті молодого покоління. Нині, коли загострилися глибинні проблеми втрати духовності, моральності, людяності в контексті грандіозних глобально-трансформаційних процесів, які переживає наша держава, стає вкрай необхідною інноваційна система навчання та виховання учнів і студентів. Як зазначає О.Чопик, ідеалом виховання є гармонійно розвинута, високоосвічена, соціально активна, національно свідома людина, наділена глибокою громадянською відповідальністю, здоровими інтелектуально-творчими, фізичними і духовними якостями, родинними та патріотичними почуттями, працьовитістю, господарською кмітливістю, підприємливістю, ініціативою [8].

У який же спосіб можливо наблизитись до такого ідеалу? На думку Г.Михайлишин, стратегічний напрям сучасної освіти полягає у формуванні всебічно розвиненої особистості, яка не лише застосовуватиме здобуті знання у своїй подальшій професійній діяльності, а й постійно оновлюватиме та поповнюватиме їх. Важливо бути не лише кваліфікованим фахівцем, а й, передусім, компетентним. Компетентний фахівець відрізняється від кваліфікованого тим, що він не лише володіє певними знаннями, уміннями та навичками, необхідними для його плідної професійної діяльності, але й реалізує їх у своїй роботі; завжди саморозвивається та виходить за межі своєї дисципліни; вважає свою професію великою цінністю. У наш час потреба в компетентності є найголовнішою ознакою та потребою кожної людини $[9,53]$.

Отже, розвиток інтелектуальних здібностей постає фундаментальною характеристикою навчання, спрямованого на підготовку 
компетентного фахівця. На думку 3.Самчука, навчання, спрямоване на розвиток інтелектуальних здібностей, розвиває передусім здатність учня здобувати об'єктивне знання про дійсність. Йдеться про те, щоб суб'єкт навчального процесу оволодів способами пошуку істини, а не був пасивним споживачем інформації. Таке навчання служить світоглядним орієнтиром, аби учень осягнув дійсність в істинному, а не віртуальному, фальшивому вигляді. Воно також підводить до розуміння теоретичних і практичних проблем буття та мислення в їх єдності $[10,7]$.

Складовою становлення інтелектуально розвиненої особистості, яка здатна до свідомого вибору життєвих цілей в умовах постійних змін, спричинених невпинним поступом інформаційної цивілізації, є політична освіта. Як зазначає С. Давидюк, необхідність розвитку політичної культури зумовлена тим, що молоді люди обстоюють свій професійний вибір у суперечливому суспільстві, сповненому невизначеності, соціальних контрастів, в умовах якого утруднюється вибір життєвих (і тим більше - політичних) орієнтирів. Програма розвитку політичної культури студентської молоді передбачає розв'язання таких завдань:

- $\quad$ розширення політичної свідомості: усвідомлення різних аспектів політичної культури, ускладнення аналізу політичної культури, активізація рефлексії суб'єкта в ситуації вибору (когнітивний компонент);

- усвідомлення варіантів своєї поведінки в контексті політичної культури, цілеспрямована Я-ідентифікація при здійсненні вибору позиції або варіанту поведінки в умовах навчального завдання (когнітивний компонент);

- $\quad$ формування позитивного ставлення до себе як суб'єкта соціальної та політичної позицій, підвищення цінностей суспільного й політичного характеру в рейтингу особистих цінностей (емоційний компонент);

- $\quad$ розширення репертуару політичної поведінки, розвиток моделей політичної поведінки в контексті політичної культури (поведінковий компонент);

- формування навичок сприйняття та розуміння життєвої перспективи, постановка власних професійних та інших особистих цілей, спираючись на категорії політичної культури (часовий компонент);

- проектування своєї майбутньої поведінки в контексті 
політичної культури та створення перспективи власного майбутнього, враховуючи варіанти свого можливого вибору (часовий компонент) [11, 110-111].

Запропонована програма є одним із перспективних варіантів реалізації гуманістичних ідей сучасної політичної освіти (і ширше освіти загалом). Її стратегічна мета полягає в утвердженні інтелекту як провідної характеристики людського життя, яка водночас не може бути зведена лише до величезного масиву інформації поза усвідомленням, ціннісним осмисленням іiі змісту і значення.

Освіта, як наголошує I.Іоненко, передусім має культивувати людяність. Справжній раціоналізм водночас є гуманізмом, оскільки спрямований на розкриття світу як упорядкованої гармонійної цілісності. Він грунтується на визнанні людини частиною цієї цілісності, що володіє часткою вселенського розуму і тому здатна осягати закони цього світу, узгоджувати 3 ними свої дії 3 метою гармонізації власних відносин із навколишньою дійсністю. На жаль, у сучасній культурі (зокрема, західній) ідеї пріоритету особистого набули гіпертрофованого характеру, перетворюючи всі прояви суб'єктивного на своєрідну «священну корову» західної культури. У західних гуманістичних теоріях суб'єктивне почало зазіхати на розум, концентруючи увагу на виявах позасвідомого. Прихильники психоаналітичних теорій не просто стимулюють інтерес суспільства до них, а, проголосивши це справжньою увагою до суб'єкта, заклопотаністю його проблемами, насправді практично сакралізували ці прояви, зробивши їх своєрідною модою, що претендує на нестандартність, оригінальність, нехтування раціоналістичних традицій. Внаслідок цього навіть найпотворніші вияви особистого (аж до реалізації тваринних інстинктів і бажань) претендують на статус таких, що не можуть бути піддані критиці, оскільки вони нібито не підлягають раціональному оцінюванню. Втрата пріоритетних позицій розуму в масовій свідомості призвела до поширення низького в культурі: в літературі, мистецтві, навіть у філософії [12, 61-62]. Доводиться констатувати, що подібна ситуація властива й сучасній вітчизняній культурі, представники якої у своїх творах досить часто ігнорують значення інтелекту.

Саме тому залучення людей до культури може бути визначене як один із головних напрямів повернення інтелекту в державотворче поле Украӥни. У більш широкому контексті процес залучення 
людей до культури має не лише державотворче, а й загальносоціальне значення, оскільки людина як об'єкт духовної культури у своїх інтересах, цінностях, орієнтирах, потребах, вчинках відображає рівень духовної культури суспільства, в якому вона живе. Водночас залучення до духовної культури розвиває духовні потреби, формує інтелектуальні, естетичні інтереси людини, відображає внутрішнє багатство, ступінь духовної зрілості, тобто ті якості, які характеризують духовну особистість - суб'єкта культури. Є. Федорова звертає особливу увагу на розвиток таких духовно-психічних процесів людини, які передують власне інтелектуальній діяльності. Йдеться про сприймання, уявлення, увагу, настанови, пам'ять, рефлексію. У навчальному процесі вони залишаються поза межами методики формування розумових дій, проте розумова діяльність починається саме 3 них. Вона починається зі сприймання, співвіднесення (зіставлення) нових знань із власним тезаурусом, з'ясування подібності і відмінності нової та старої інформації, виокремлення сфери розбіжності, зі спроб розв'язати виниклі суперечності через аналіз понять, їх зв'язків, з доповнення або переструктурування наукового тезаурусу, яке здійснюється через логіку, рефлексію й евристику мислення [13, 372].

Зазначені механізми розумової діяльності відіграють провідну роль у залученні людей до культури і відповідно створюють умови для повернення інтелекту в державотворче поле України. На цьому шляху слід уникати духовних помилок. Духовна помилка - це не економічний чи політичний прорахунок, не слабкість у знанні математики або риторики, це - помилка цивілізаційна, що виникає як наслідок ігнорування історичної традиції, нерозуміння того зв'язку, який існує між історичним минулим, сьогоденням і майбутнім даної цивілізації. На думку В.Пашкова, інтелекту українського суспільства властиві два види духовних помилок:

- помилка «критичного розуму» - прагнення негайно усунути в житті суспільства все, що здається невідповідним вимогам чистого розуму. Для критичного розуму характерні безкомпромісність і моральна нещадність, він набуває рис архетипу перебудови в українській самосвідомості. Зокрема, так звані реформи 90-х років XX ст., в яких проявилися тенденції своєрідного поєднання устремлінь номенклатури 3 дисидентством, визначили неминучість розпаду системи державного управління, політику обвальної приватизації, 
радикальної лібералізації цін і різкої соціальної диференціації, що призвело до глибокої соціально-економічної кризи в Україні;

- помилка «пророчої парадигми». У релігійній свідомості пророча парадигма вважається наслідком одкровення. Український інтелектуалізм вбачає в парадигмі пророчого мислення три основні ланки: джерело абсолютної істини (західний інтелектуальний авторитет); посередник - це пророк, який довідався про істину (український інтелектуал, залучений до абсолютного знання); народ, здатний дізнатися істину (профанна маса, якій недоступне першоджерело абсолютного знання).

Сумарним наслідком духовних помилок в Україні стає їі відтворення як порожнього цивілізаційного простору. Презирливе ставлення до власної країни, періодична зміна стратегічних орієнтацій ці позиції інтелектуальних еліт України на Заході сприймаються прихильно [14, 80].

У зв'язку з цим варто приділити особливу увагу проблемі залучення людини (передусім - молоді) до цінностей вітчизняної культури, що має сприяти поверненню інтелекту в державотворче поле України. Українська традиційна народна культура є ядром національної культури й важливим чинником формування національної ідентичності. Стійкість і стабільність традиційних цінностей пов'язані з тим, що вони засвоюються з досвіду не одного попереднього покоління та можуть переходити до поколінь наступних.

Безумовно, цінності певним чином змінюються разом із суспільними трансформаціями, причому важливого значення набуває їх моральна складова. Зміни, що відбуваються в соціально-політичному, економічному та культурному житті України, актуалізують проблеми виховання молодого покоління на нових соціальних і національно-культурних засадах [15].

У сучасному українському суспільстві динаміку ціннісних орієнтацій визначає дисбаланс між матеріальними та духовними цінностями (це характерно для всіх суспільств, що трансформуються), відбувається переосмислення усталених норм і цінностей. Цей дисбаланс пояснюється, передусім, такими чинниками, як ринкові перетворення в економіці, трансформація відносин власності, зміна соціальної структури суспільства, збідніння значної частини населення, відносно нова європейська ідентичність, ідеологічна багатовекторність і різноспрямованість українського суспільства. 
На тлі домінування ірраціоналізму у світогляді суспільства, експансії масової комерційної культури, насадження психології споживацтва, переорієнтації на прагматичні цінності, відсутності цікавості до моральних і духовних надбань відбуваються деградація суспільства, примітивізація смислу людського буття, навіть недооцінювання людського життя. Це, у свою чергу, стимулює асоціальні і протиправні форми самореалізації особистості - алкоголізм, наркоманію, проституцію, злочинність, зумовлює масове поширення містичних учень, нетрадиційних культів, які є реальною загрозою для фізичного здоров'я та духовного розвитку молодого покоління $[16,30]$.

Отже, утвердження інтелекту як провідного засобу подолання цих негативних явищ передбачає врахування реальних соціокультурних відносин та їх корекцію особливо серед молоді. Дослідження засвідчують існування двох основних видів соціокультурних зв'язків у сучасному молодіжному середовищі. Перший ще спирається (щоправда, дуже слабко) на традиційні культурні інтереси й потреби молоді, використовує соціальний досвід виживання, котрим багата історична традиція нашої держави. Другий пов'язаний із появою модернізованих культурних зв'язків як особливого виду соціокультурних відносин, пристосованих до нових умов життя, в обставинах поступової втрати культурних традицій. На їх розвиток вплинула нова масова культура, а також культурна експансія ззовні.

Специфіка масової культури пов'язана з ії загальнодоступним характером. Така доступність, зазначає А.Зуєв, набувши знаковоінформаційної форми, призвела до цивілізаційної ситуації, в якій кожен може уявити себе всемогутнім, насправді будучи абсолютно нездатним до жодної культурної дії. Людина, виробляючи та маніпулюючи інформацією, із задоволенням перебуває у стані самоомани, вважаючи таке продукування за творчість, а його результати за наслідки своїх духовно-культурних прагнень і зусиль.

Сучасна масова культура стала всеосяжним явищем, яке здатне залучати будь-що до своєї інформаційної матриці. В інформаційній цивілізації будь-які зміни у виробничій, соціально-економічній, політичній, розважальній сферах насправді не несуть жодної новизни: адже вони змінюють не сутність, а лише знакову форму. Такі зміни, з одного боку, задовольняють (нехай навіть в ілюзор- 
ній формі) прагнення людини до руху, а з іншого, - не загрожують цивілізаційному функціонуванню, не змінюючи його внутрішню сутність [17, 130-131].

Відмова держави від традиційних культурно-просвітницьких, соціальних функцій, передача цих функцій, прав та відповідальності в інші руки (приватним підприємцям, закордонним інститутам, фірмам, суспільним організаціям), фактична відмова від функцій контролю за діяльністю цих нових утворень, на думку Ю.Сугробова, призвели до швидкої втрати самих цих культурних цінностей і здобутків, до девальвації їх у свідомості молоді, деінтелектуалізації нових поколінь, заміни в їхній свідомості справжніх цінностей уявними.

Фактично, виросло вже ціле покоління молодих людей, частково чи повністю позбавлених соціально-культурних коренів, відірваних від живого, питомого середовища національної культури, місце якої заповнене і продовжує заповнюватися гіршими зразками ерзац-культури. 3 іншого боку, структурні й інституціональні зміни в переконаннях різних поколінь, статусних груп, суб'єктів політичних інтересів здатні викликати як руйнування, так і відродження суспільства на нових ціннісно-розумових, економічних, політичних, духовних засадах.

У час, коли соціальні відносини у своєму об'єктивному розвитку утворюють основу для поділу суспільства, саме культура, фундаментальні загальнолюдські й національні цінності постають духовним джерелом і механізмом суспільної інтеграції [18, 325].

Отже, процеси розвитку інформаційної цивілізації актуалізують осмислення проблеми інтелекту, поглиблюючи й урізноманітнюючи зміст цивілізації. Інтелект постає інтегральною характеристикою сучасного суспільства, що може бути одночасно визначеним як мета і засіб державотворення. Його зміст як основного чинника розвитку постіндустріальної цивілізації визначається наданням людині умов для творчості, вдосконаленням навколишнього середовища, постійним освоєнням нової інформації, що в умовах інформаційної революції постає невичерпним джерелом нових знань. Інтелект перетворюється на провідний ресурс державного будівництва.

\section{ЛIТЕРАТУРА}


1. Пірко М.В. Розвиток інтелектуальної сфери в процесі інформатизації навчання. - Режим доступу: www.psy-science.com.ua/department/texty/ konf0902/pirko.doc

2. Пашков В.В. Ідеологія сучасної безперервної освіти // Грані. - 2012. №4 (84). - C. 77-81.

3. Чорний А.B. Державне управління інноваційним відтворенням інтелектуальних ресурсів // Актуальні проблеми економіки. - 2010. - №12 (114). - C.82-90.

4. Михайлишин Г. Філософський аналіз кризових явищ у сучасному освітньому процесі // Гуманітарний вісник ДВНЗ «Переяслав-Хмельницький державний педагогічний університет імені Григорія Сковороди». 2012. - Вип. 26. - С.417-423.

5. Діденко Л.В. Інтелектуально-креативні перетворення у виш-освіті: виклики майбутнього і відповіді сучасності // Вісник Київського національного університету імені Тараса Шевченка. - 2012. - Військовоспеціальні науки. - Вип. 28. - С.44-46.

6. Драйден Г. Революція в навчанні / Г. Драйден, Дж. Вос - пер. $з$ англ. Львів, 2005. - 542 с.

7. Пунченко О.П. Інституціональна сфера освіти та іiі функціональна спрямованість // Гуманітарний вісник ЗДІА. - 2011. - №45. - С. 12-20.

8. Чопик О.Я. Гуманізація освіти та інтелектуальний потенціал суспільства [Електронний ресурс]. - Режим доступу: www.nbuv.gov.ua/portal/ soc_gum/intelekt/2008_6/48.pdf.

9. Михайлишин Г.Й. Актуальні проблеми створення сучасної моделі інноваційної освіти в Україні // Грані. - 2012. - №9 (89). - С.51-55.

10. Самчук 3. Концептуальні пріоритети науково-освітньої сфери як елемент системи суспільної модернізації // Філософія освіти. - 2010. №1-2 (9). - C. 7-30.

11. Давидюк $C$. Програма розвитку політичної культури студентів університету: теоретичні основи // I Всеукраїнська науково-практична конференція «Психолого-педагогічні та політичні проблеми у трансформаційних процесах українського суспільства». Матеріали конференції. Кременчук, 2012. - С. 110-111.

12.Ионенко И.Р. Рационализм - это гуманизм // Інтелект. Особистість. Цивілізація. - 2009. - Вип. 7. - С. 56-64.

13. Федорова Є.B. Зв'язок інтелекту та духовності як основа професіоналізму майбутніх фахівців // Проблеми загальної та педагогічної психології. - 2011. - Т. XIV. - Ч.2. - С.367-373.

14. Пашков В.В. Ідеологія сучасної безперервної освіти // Грані. - 2012. №4 (84). - C. 77-81.

15. Семенова М.О. Залучення молодших школярів до цінностей українсь- 
кої традиційної народної культури [Електронний ресурс]. - Режим доступу: www.nbuv.gov.ua/portal/soc_gum/pfto/2010_10/files/p1010_48.pdf. 16. Авер'янова Н. Сучасне студентство у контексті формування національної еліти України // Вісник Київського національного університету імені Тараса Шевченка. - 2010. - Українознавство. - Вип. 14. - С.30-32.

17. Зусв А.В. Феномен залучення до масової культури // Філософські науки. - 2009. - Вип. 1. - С. 129-135.

18. Сугробова Ю.Ю. Переваги молоді в соціокультурному просторі України // Наукові праці історичного факультету Запорізького національного університету. - 2010. - Вип. XXVIII. - С.323-326.

Отрешко В.С. Пріоритет інтелекту, совісті і культури в структурі українського державотворення.

У статті розглядається значення інтелекту, освіти і культури в структурі українського державотворення. Звертається увага на освіту в сучасному інформаційному суспільстві та ії проблеми в освітніх системах. Завдяки стрімкому розвитку інформаційного суспільства підвищуються вимоги до системи освіти, де головним завданням $€$ пошук талантів серед підростаючого покоління. Проаналізовано кризові явища освітньої системи, проводиться паралель між поняттями «кваліфікований фахівець» і «компетентний фахівець», порушуються питання про інноваційну систему навчання та виховання. Розглядається програма розвитку політичної культури молоді

Ключові слова: інтелект, освіта, культура, державотворення.

Отрешко В.С. Приоритет интеллекта, совести и культуры в структуре украинского государства.

В статье рассматривается значение интеллекта, образования и культуры в структуре украинского государственного строительства. Обращается внимание на образование в современном информационном обществе и его заостренные проблемы в образовательных системах. Благодаря стремительному развитию информационного общества повышаются требования к системе образования, где главной задачей является поиск талантов среди подрастающего поколения. Проанализированы кризисные явления образовательной системы, проводится параллель между понятиями «квалифицированный специалист» и «компетентный специалист»; поднимаются вопросы об инновационной системе обучения и воспитания. Рассматривается программа развития политической культуры молодежи.

Ключевые слова: интеллект, образование, культура, создание государства. 
Otreshko V. Priority of intellect, conscience and culture in the structure of Ukrainian state creation.

Advantages of intellect, education and culture in the structure of Ukrainian state creation were reviewed in the paper. Attention was paid to education which has a significant importance in modern information society and its acute issues in educational systems. Owing to rapid development of information society, requirements to the system of education increase where the main task is the search of talents and skills among the young generation; crisis events of educational system and their reformation were analyzed; a parallel was drawn between the concepts qualified specialist and competent specialist; issues of intensification of values of education of young generation were brought up and as a result, solving of the issue becomes necessary innovative system of education and upbringing. Program of developing political culture of the youth which solves certain tasks; culture as one of the directions of return of intellect.

Key words: intellect, education, culture, creation of the state. 